\title{
Rhizobium vallis sp. nov., isolated from nodules of three leguminous species
}

\author{
Fang Wang, ${ }^{1}$ En Tao Wang, ${ }^{1,2} \mathrm{Li}$ Juan $\mathrm{Wu}^{1}{ }^{1}$ Xin Hua Sui, ${ }^{1}$ Ying $\mathrm{Li}, \mathrm{Jr}^{1}$ \\ and Wen Xin Chen ${ }^{1}$
}

Correspondence

Wen Xin Chen

wenxin@cau.edu.cn

\author{
${ }^{1}$ State Key Lab for Agrobiotechnology, College of Biological Sciences and Center for Biomass \\ Engineering, China Agricultural University, Beijing 100193, PR China \\ ${ }^{2}$ Departamento de Microbiología, Escuela Nacional de Ciencias Biológicas, Instituto Politécnico \\ Nacional, 11340 México D. F., Mexico
}

\begin{abstract}
Four bacterial strains isolated from root nodules of Phaseolus vulgaris, Mimosa pudica and Indigofera spicata plants grown in the Yunnan province of China were identified as a lineage within the genus Rhizobium according to the analysis of 16S rRNA gene sequences, sharing most similarity with Rhizobium lusitanum $\mathrm{P} 1-7^{\top}$ (99.1\% sequence similarity) and Rhizobium rhizogenes IAM $13570^{\top}$ (99.0\%). These strains also formed a distinctive group from the reference strains for defined species of the genus Rhizobium in a polyphasic approach, including the phylogenetic analyses of the 16S rRNA gene and housekeeping genes ( $\operatorname{rec} A$, atp $D, g / n I I)$, DNA-DNA hybridization, BOX-PCR fingerprinting, phenotypic characterization, SDS-PAGE of whole-cell proteins, and cellular fatty acid profiles. All the data obtained in this study suggested that these strains represent a novel species of the genus Rhizobium, for which the name Rhizobium vallis sp. nov. is proposed. The DNA G+C content (mol\%) of this species varied between 60.9 and $61.2\left(T_{\mathrm{m}}\right)$. The type strain of $R$. vallis sp. nov. is CCBAU $65647^{\top}$ (=LMG $25295^{\top}=\mathrm{HAMBI} 3073^{\mathrm{T}}$ ), which has a DNA G $+\mathrm{C}$ content of $60.9 \mathrm{~mol} \%$ and forms effective nodules on Phaseolus vulgaris.
\end{abstract}

Rhizobia are symbiotic nitrogen-fixing bacteria that reduce $\mathrm{N}_{2}$ to ammonia after forming root and/or stem nodules with leguminous plants. To date, about 80 rhizobial species have been reported within the four main genera Rhizobium, Ensifer (Sinorhizobium), Mesorhizobium and Bradyrhizobium, as well as in several other genera in the classes Alphaproteobacteria and Betaproteobacteria (Wang et al., 2006). The genus Rhizobium (Frank, 1889) was the first and only rhizobial genus described for a century, before the genus Bradyrhizobium was reported (Jordan, 1982). Since then, a series of taxonomic changes have been made in the genus Rhizobium and at the time of writing it contains 47 species, including the recently described species Rhizobium soli (Yoon et al., 2010), Rhizobium borbori (Zhang et al., 2011b), Rhizobium vignae (Ren et al., 2011) and Rhizobium tubonense (Zhang et al., 2011a).

\footnotetext{
The GenBank/EMBL/DDBJ accession numbers for the $16 \mathrm{~S}$ rRNA, atpD, recA and glnll gene sequences of strains CCBAU $65647^{\top}$, CCBAU 65648, CCBAU 65643 and CCBAU 65751 are FJ839677, GU211765, GU211766 and EU618035 (16S rRNA gene), GU211768, HM453324, HM453323 and EU617993 (atpD), GU211770, HM453320, HM453319 and EU622122 (recA), and GU211771, HM453322, HM453321 and EU618013 ( $\mathrm{g} / \mathrm{n} / \mathrm{l})$, respectively.
}

Two supplementary tables and two supplementary figures are available with the online version of this paper.
In a survey of rhizobial resources in Yunnan, a tropical province of China, four strains isolated from root nodules of Phaseolus vulgaris, Mimosa pudica and Indigofera spicata were identified as a distinct lineage in the genus Rhizobium by sequence analysis of the $16 \mathrm{~S}$ rRNA gene, which was used to screen all the isolates. In order to clarify the taxonomic position of the four strains, a polyphasic study including phylogenetic analyses of the 16S rRNA gene and housekeeping genes ( $r e c A$, atpD, glnII), BOX-PCR fingerprinting, DNADNA hybridization, phenotypic characterization, SDS-PAGE of whole-cell proteins, and cellular fatty acid composition was performed in comparison with reference strains of defined species of the genus Rhizobium. Based on the results, these four isolates represent a different group from all defined species and, therefore, a novel species is proposed.

The four novel bacterial strains and the reference strains used in this study are presented in Table 1. All the bacterial strains were maintained on yeast mannitol agar (YMA; Vincent, 1970) at $4{ }^{\circ} \mathrm{C}$ for short-term storage and in YM broth (Vincent, 1970) supplemented with $20 \%$ (w/v) glycerol at $-80{ }^{\circ} \mathrm{C}$ for long-term storage.

Genomic DNA was extracted from each of the four novel strains by the method of Terefework et al. (2001) and used as template for $16 \mathrm{~S}$ rRNA gene amplification. The almost complete $16 \mathrm{~S}$ rRNA gene was amplified with the primers P1 
Table 1. Isolates and reference strains used in this study

\begin{tabular}{|c|c|c|}
\hline Strain $^{*}$ & Host plant & Geographical origin \\
\hline \multicolumn{3}{|l|}{ Rhizobium vallis sp. nov. } \\
\hline CCBAU $65647^{\mathrm{T}}$ & Phaseolus vulgaris & Yunnan, China \\
\hline CCBAU 65648 & Phaseolus vulgaris & Yunnan, China \\
\hline CCBAU 65643 & Indigofera spicata & Yunnan, China \\
\hline CCBAU 65751 & Mimosa pudica & Yunnan, China \\
\hline \multicolumn{3}{|l|}{ Reference strains } \\
\hline R. etli CFN $42^{\mathrm{T}}$ & Phaseolus vulgaris & Mexico \\
\hline R. leguminosarum USDA $2370^{\mathrm{T}}$ & Pisum sativum & USA \\
\hline R. rhizogenes IAM $13570^{\mathrm{T}}$ & Phaseolus vulgaris & \\
\hline R. tropici IIA LMG 9517 & Phaseolus vulgaris & Brazil \\
\hline R. tropici IIB LMG $9503^{\mathrm{T}}$ & Leucaena leucocephala & Colombia \\
\hline R. lusitanum LMG $22705^{\mathrm{T}}$ & Phaseolus vulgaris & Portugal \\
\hline R. miluonense CCBAU $41251^{\mathrm{T}}$ & Lespedeza chinensis & Hunan, China \\
\hline R. multihospitium CCBAU $83401^{\mathrm{T}}$ & Halimodendron halodendron & Xinjiang, China \\
\hline
\end{tabular}

${ }^{*}$ CCBAU, Culture Collection of Beijing Agricultural University, Beijing, PR China; CFN, Centro de Investigación sobre Fijación de Nitrógeno, UNAM, Mexico; USDA, US Department of Agriculture Agricultural Research Service National Rhizobium Culture Collection; IAM, Institute of Applied Microbiology, The University of Tokyo, Tokyo, Japan; LMG, Collection of the Laboratorium voor Microbiologie en Microbiele Genetics, Gent, Belgium.

and P6 (Chen et al., 1995) and sequenced directly as described by Hurek et al. (1997). All sequences were aligned using the CLUSTAL $\mathrm{W}$ program in the MEGA 4.0 software (Tamura et al., 2007). Distances were calculated according to the models of Jukes \& Cantor (1969), Tajima \& Nei (1984), Tamura \& Nei (1993) and Kimura's two-parameter (Kimura, 1983). Phylogenetic trees based upon 16S rRNA gene sequences were reconstructed with the neighbourjoining, maximum-parsimony and maximum-likelihood methods and were bootstrapped with 1000 replications. Regardless of tree reconstruction method, similar topology was obtained in all phylogenetic trees, and only the neighbour-joining tree with the model of Jukes \& Cantor (1969) is shown in Fig. 1. The four novel strains had almost identical 16S rRNA gene sequences $(99.9 \%$ to $100 \%$ similarities) and formed a unique phylogenetic lineage in the genus Rhizobium (Fig. 1). The representative strain, CCBAU $65647^{\mathrm{T}}$, showed $99.1 \%$ similarity with Rhizobium lusitanum $\mathrm{P} 1-7^{\mathrm{T}}$, 99.0\% similarity with Rhizobium rhizogenes IAM $13570^{\mathrm{T}}$ and 98.8, 98.7, 98.5, 98.5, 98.2 and $97.7 \%$ similarity, respectively, with Rhizobium miluonense CCBAU $41251^{\mathrm{T}}$, Rhizobium multihospitium CCBAU $83401^{\mathrm{T}}$, Rhizobium etli CFN $42^{\mathrm{T}}$, Rhizobium tropici IIA LMG 9517, Rhizobium tropici IIB CIAT $899^{\mathrm{T}}$ and Rhizobium leguminosarum bv. viciae USDA $2370^{\mathrm{T}}$.

DNA-DNA hybridization is considered to be a standard method for species definition and the recommended minimum value for strains of the same species is $70 \%$ (Graham et al., 1991; Wayne et al., 1987). To determine DNA-DNA relatedness and DNA base composition, total DNA was extracted from each strain using the method of Marmur (1961). DNA-DNA hybridization was performed using the initial renaturation rate method (De Ley et al., 1970). DNA-DNA relatedness values between strain CCBAU $65647^{\mathrm{T}}$ and the other three strains were 97.3, 96 and $82.2 \%$, respectively, which is above the species threshold of $70 \%$, indicating that they were the same genomic species. Strain CCBAU $65647^{\mathrm{T}}$ showed 39.3 and $39.4 \%$ DNA-DNA relatedness, respectively, with the most related strains, $R$. rhizogenes IAM $13570^{\mathrm{T}}$ and $R$. lusitanum P $1-7^{\mathrm{T}}$ (Supplementary Table S1 available in IJSEM Online), which was much lower than the species threshold. These results suggested that the genomic species represented by strain CCBAU $65647^{\mathrm{T}}$ was different from defined species.

The DNA G + C content was $60.9 \mathrm{~mol} \%\left(T_{\mathrm{m}}\right)$ for strain CCBAU $65647^{\mathrm{T}}$ and $61.2 \mathrm{~mol} \%$ for strain CCBAU 65751, measured using the thermal denaturation method of Marmur \& Doty (1962), with Escherichia coli K-12 as a standard. These values were within the range for members of the genus Rhizobium (Jordan, 1982).

The concatenation of housekeeping gene sequences has been suggested as an easy tool to assess interorganismal relationships (Martens et al., 2008). In the present study, using the same template DNA used for 16S rRNA gene amplification and the PCR protocols of Vinuesa et al. (2005a), the housekeeping genes $a t p D, r e c A$ and $g \ln I I$ were amplified separately with the primer pairs atpD255F and atpD782R, recA41F and recA640R, and $g \ln I I 12 \mathrm{~F}$ and $g \ln I I 689 \mathrm{R}$, respectively (Gaunt et al., 2001; Turner \& Young, 2000; Valverde et al., 2006; Vinuesa et al., 2005a, b). The PCR products were sequenced directly and a phylogenetic tree (Supplementary Fig. S1) was reconstructed based on the concatenated gene sequences ( $a t p D$, rec $A$ and $g \ln I I)$ by using MEGA 4.0 software. In the concatenated tree, the novel strains 


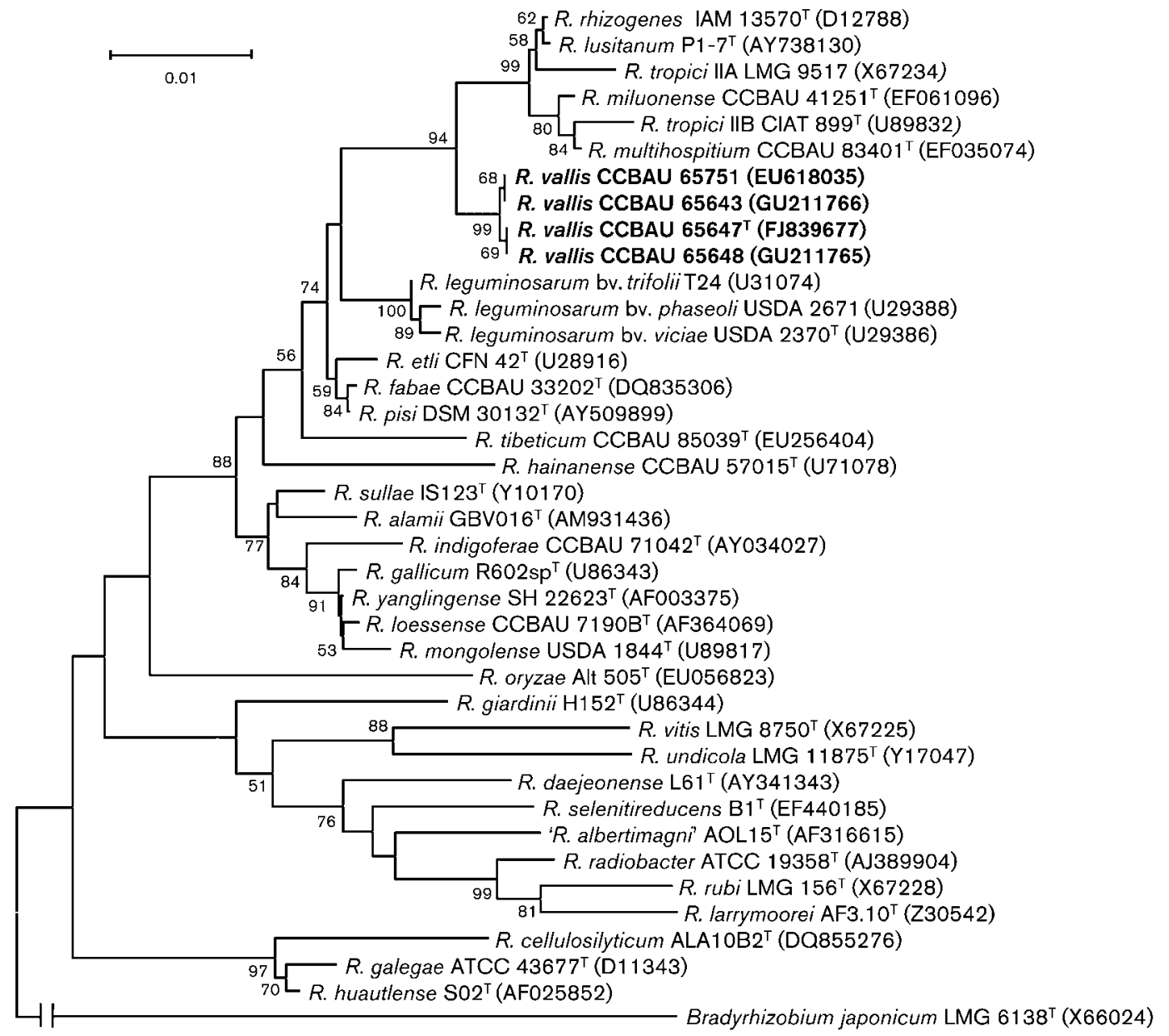

Fig. 1. Neighbour-joining tree based on nearly complete 16S rRNA gene sequences of Rhizobium vallis sp. nov. strains (in bold face) and closely related species within the genus Rhizobium. The significance of each branch is indicated by a bootstrap value calculated for 1000 subsets. Bar, $1 \%$ nucleotide substitutions.

formed two lineages in a subclade together with reference strains for Rhizobium leguminosarum and Rhizobium etli, demonstrating that these four strains represent diverse populations and that their housekeeping genes have evolved divergently.

The symbiotic genes (nod) are required for the successful establishment of highly specific symbiosis between rhizobia and legumes, and are important determinants of rhizobial host specificity (Guan et al., 2008). Therefore, comparisons of symbiotic genes may reveal the host ranges of rhizobia and allow estimation of their symbiotic properties (Kalita et al., 2006; Laranjo et al., 2008; van Berkum et al., 2007). In this study, partial nodC ( $N$-acetylglucosaminyltransferase) fragments were amplified with the previously described primers NodC540 and NodC1160 (Sarita et al., 2005) from strains CCBAU $65647^{\mathrm{T}}$ and CCBAU 65648. The amplified fragments were directly sequenced with the same primers. No nodC fragment was amplified from strains CCBAU 65643 and CCBAU 65751 with these primers and nodCF and nodCI (Laguerre et al., 2001). In the phylogenetic analysis of $\operatorname{nodC}$ (Fig. 2), strain CCBAU $65647^{\mathrm{T}}$ had $100 \%$ sequence similarity with strain CCBAU 65648 and the three reference strains $R$. leguminosarum bv. phaseoli $\mathrm{H} 132$, Rhizobium giardinii bv. phaseoli $\mathrm{H} 251$ and Rhizobium gallicum bv. phaseoli $\mathrm{PhD12}$, which was independent from the phylogeny of the $16 \mathrm{~S}$ rRNA and housekeeping genes. All of these reference strains are symbionts of Phaseolus vulgaris. The nodC sequence similarities were $\leqslant 71.2 \%$ between CCBAU $65647^{\mathrm{T}}$ and other reference strains belonging to $R$. tropici, R. leguminosarum, R. giardinii, R. etli and others.

BOX-PCR fingerprinting is widely applied for characterization and identification of bacterial strains (de Bruijn, 1992; Huber \& Selenska-Pobell, 1994; Judd et al., 1993; Nick \& Lindstrom, 1994; Nick et al., 1999). BOX-PCR was performed by using the primer BOXAIR (5'-CTACGGCAAGGCGACGCTGACG-3') and procedure of Versalovic et al. (1994). The amplified products were separated by electrophoresis in $1.5 \%(\mathrm{w} / \mathrm{v})$ agarose gels stained with ethidium bromide. The fingerprints were analysed by the Gelcompar II program (Applied Maths) and an unweighted 


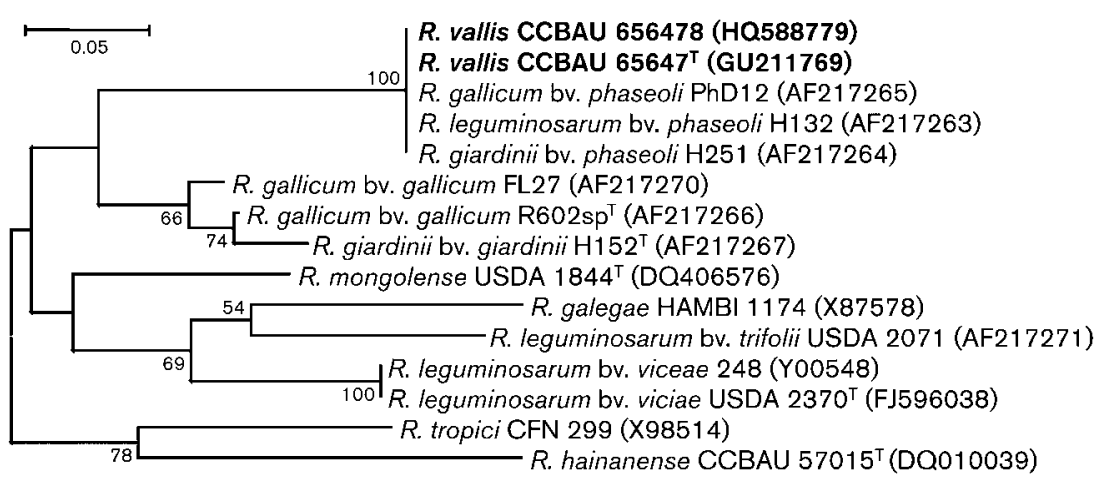

Fig. 2. Neighbour-joining dendrogram based on nodC gene sequences showing the relationships among representative strains of Rhizobium vallis $\mathrm{sp}$. nov. and related species. Bootstrap confidence levels greater than $50 \%$ are indicated at nodes. Bar, $5 \%$ nucleotide substitutions. pair group method with arithmetic mean (UPGMA) dendrogram was reconstructed using the BOX-PCR profile. All the test strains had unique BOX-PCR fingerprints, indicating that they were not clones, and these strains formed a cluster at a similarity level of $94 \%$ (Fig. 3), which was greater than the similarities obtained among the recognized species of the genus Rhizobium.

SDS-PAGE of whole-cell proteins has been used widely in rhizobial taxonomy (Diouf et al., 2000; Tan et al., 1997; Wang et al., 2006) and is suitable to group strains at species level. Methods described previously (Tan et al., 1997; Wang et al., 2006) were applied to extract whole-cell proteins from the test strains and to perform SDS-PAGE analysis. Digitization, normalization and numerical analyses of the protein profiles were performed with the GelCompar II version 4.5 software (Applied Maths). Similarities between pairs of protein patterns were expressed by the Pearson's coefficient and an UPGMA dendrogram was reconstructed (Vauterin \& Vauterin, 1992). The four novel strains formed a cluster at a similarity level of $73 \%$ (Supplementary Fig. S2), which was quite different from recognized species of the genus Rhizobium and was greater than the similarities obtained among the reference strains of $R$. tropici, $R$. multihospitium, $R$. rhizogenes and $R$. lusitanum. These data showed that the four strains were different strains with similar genomic backgrounds.
Phenotypic characteristics of the four novel strains and reference strains of the most closesly related species of the genus Rhizobium were tested using the methods of Gao et al. (1994), including 45 different carbon sources and 13 amino acids as sole nitrogen sources, resistance to various antibiotics $\left(300,100,50\right.$ and $\left.5 \mu \mathrm{g} \mathrm{ml}^{-1}\right)$, tolerance to salt $(0-5 \%, w / v)$, temperature range for growth $(4,10,28,37$ and $\left.45^{\circ} \mathrm{C}\right)$ and $\mathrm{pH}(4.0,5.0,6.0,7.0,8.0,9.0,10.0$ and 11.0). Production of catalase, urease, L-phenylalaninase and oxidase, nitrate reduction, and reaction in litmus milk were also studied. Some distinctive features are listed in Table 2. The results demonstrated that the four test strains had very similar features and formed a phenon sharing similarities greater than $80 \%$, a value recommended as a threshold for delineating species of the genus Rhizobium (Chen et al., 1988; Gao et al., 1994), and this phenon could be distinguished by several distinctive characteristics from closely related species of the genus Rhizobium (Table 2).

Differences in fatty acid profiles, which are in broad agreement with 16S rRNA gene sequence similarities and appear to accurately distinguish most species, have been used to describe novel bacterial species (Quan et al., 2005; Schutter \& Dick, 2000; Tighe et al., 2000). In this study, the fatty acids were analysed for strain CCAU $65647^{\mathrm{T}}$ and the reference strains R. etli CFN $42^{\mathrm{T}}, R$. huautlense $\mathrm{S} 02^{\mathrm{T}}$ and $R$. leguminosarum USDA $2370^{\mathrm{T}}$. After $72 \mathrm{~h}$ of incubation at

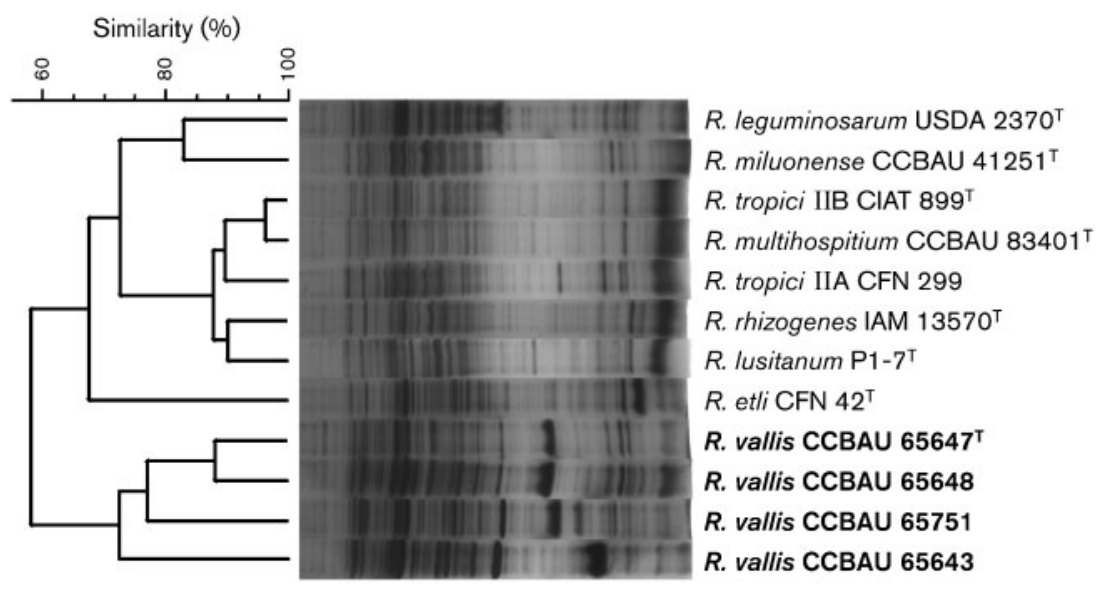

Fig. 3. Electrophoretic protein patterns showing the relationships between strains of Rhizobium vallis sp. nov. (in bold face) and reference strains of phylogenetically related species. 
Table 2. Distinctive features of Rhizobium vallis sp. nov. and phylogenetically related species

Strains: $1, R$. vallis sp. nov. $(n=4) ; 2, R$. rhizogenes IAM $13570^{\mathrm{T}} ; 3, R$. lusitanum $\mathrm{P} 1-7^{\mathrm{T}}$; 4, R. multihospitium CCBAU $83401^{\mathrm{T}}$; 5, R. tropici IIA CFN 299; 6, $R$. tropici IIB CIAT $899^{\mathrm{T}}$; 7, Rhizobium miluonense CCBAU $41251^{\mathrm{T}}$; 8, R. leguminosarum USDA $2370^{\mathrm{T}}$; 9 , R. etli CFN $42^{\mathrm{T}}$; + , Positive; - , negative. Numbers represent the percentage of the strains with a positive reaction.

\begin{tabular}{|c|c|c|c|c|c|c|c|c|c|}
\hline Characteristic & 1 & 2 & 3 & 4 & 5 & 6 & 7 & 8 & 9 \\
\hline \multicolumn{10}{|l|}{ Utilization as sole carbon source } \\
\hline Amygdalin & 25 & + & + & + & + & - & + & + & + \\
\hline Calcium gluconate & - & - & + & + & - & - & - & - & - \\
\hline Calcium malonate & - & + & - & - & + & + & + & + & - \\
\hline Dextrin & - & + & + & - & - & - & - & - & - \\
\hline meso-Erythritol & - & + & + & + & + & + & + & + & + \\
\hline Inulin & - & - & + & - & - & - & - & + & - \\
\hline Sodium DL-malate & - & + & + & + & + & + & - & + & + \\
\hline Sodium pyruvate & - & - & + & + & + & + & + & + & - \\
\hline D-Ribose & 75 & + & - & + & + & + & + & + & + \\
\hline Salicin & + & + & + & + & - & - & + & + & + \\
\hline Sodium acetate & - & - & + & - & - & - & + & + & + \\
\hline Sodium citrate & - & - & + & + & + & + & - & - & + \\
\hline Sodium D-gluconate & - & - & + & + & - & - & - & + & - \\
\hline Sodium hippurate & - & - & - & - & - & - & - & + & - \\
\hline Trehalose & + & - & + & + & + & + & + & - & - \\
\hline L-Arginine & - & + & + & - & + & + & - & - & + \\
\hline DL-Asparagine & - & - & + & - & + & + & - & - & + \\
\hline DL-Proline & 75 & - & + & + & - & - & - & + & + \\
\hline \multicolumn{10}{|l|}{ Resistance to $\left(\mu \mathrm{g} \mathrm{ml}^{-1}\right)$ : } \\
\hline Gentamicin sulfate (5) & - & + & - & + & + & + & - & - & + \\
\hline Erythromycin (5) & 50 & + & + & + & + & + & + & + & + \\
\hline Neomycin (50) & - & + & + & + & + & - & - & + & + \\
\hline Ampicillin (50) & - & + & + & + & - & + & + & + & + \\
\hline Ampicillin (100) & - & - & + & + & - & + & + & - & - \\
\hline Ampicillin (300) & - & - & - & + & - & + & - & - & - \\
\hline Kanamycin (5) & + & + & + & + & + & + & - & + & + \\
\hline Kanamycin (50) & - & + & + & + & - & - & - & + & + \\
\hline Streptomycin sulfate (5) & - & + & + & + & - & + & + & + & + \\
\hline Streptomycin sulfate $(50)$ & - & - & + & + & - & + & - & + & + \\
\hline Streptomycin sulfate (100) & - & - & - & + & - & - & - & + & + \\
\hline Chloramphenicol (5) & - & + & + & + & + & - & + & + & + \\
\hline Chloramphenicol (50) & - & - & + & + & - & - & - & + & + \\
\hline Tolerance to $1 \% \mathrm{NaCl}(\mathrm{w} / \mathrm{v})$ & - & + & + & - & - & + & - & - & + \\
\hline Acid production in litmus milk & + & + & + & + & - & + & - & + & + \\
\hline $\begin{array}{l}\text { Alkaline production in litmus } \\
\text { milk }\end{array}$ & - & - & - & - & + & - & + & - & - \\
\hline Litmus acid coagulation & + & - & + & + & - & + & - & - & + \\
\hline
\end{tabular}

$28{ }^{\circ} \mathrm{C}$ on YMA, well-grown cells were harvested and fatty acids were extracted (Hou et al., 2009) and identified by the standard method of the Microbial Identification System (MIDI) with an HP 6890 GC using the database TSBA6 for identification of the peaks. The cellular fatty acid profile of the novel group was compared with those of related species of the genus Rhizobium (Supplementary Table S2). The novel strains could be assigned to the genus Rhizobium because they possessed the major fatty acids $16: 0,16: 0$
3-OH, 18:0, 19:0 cyclo $\omega 8 c$, summed feature 2 and summed feature 8 (Hou et al., 2009), which are common in members of the genus Rhizobium. The novel strain could be differentiated from other species of the genus Rhizobium particularly by the presence of relatively smaller amounts of $17: 0$ cyclo, $14: 0$ and summed feature 5 and larger

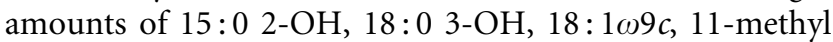
$18: 1 \omega 7 c$ and $19: 0$ cyclo $\omega 8 c$. The novel strain does not contain 13:0 2-OH, iso-15:0, iso-15:0 3-OH, anteiso$15: 0$, iso-15: $1 \mathrm{G}$ or $20: 2 \omega 6,9 c$ (Supplementary Table S2).

Nodulation and nitrogen fixation abilities are important characteristics for species of the genus Rhizobium and host range is an important feature for the description of novel rhizobial species (Graham et al., 1991). To check the host range and cross-nodulation, seeds of Phaseolus vulgaris, Mimosa pudica, Medicago sativa, Trifolium repens, Leucaena leucocephala and Indigofera spicata were surface-sterilized, germinated and inoculated with strain CCBAU $65647^{\mathrm{T}}$ by the methods of Trujillo et al. (2005). The seeds of Mimosa pudica and Indigofera spicata were also inoculated with strains CCBAU 65643 and CCBAU 65751. After growing for 7 weeks under natural sunlight in a greenhouse, effective nodules were observed on roots of Phaseolus vulgaris inoculated with strain CCBAU $65647^{\mathrm{T}}$, while no nodules were found on Mimosa pudica, Medicago sativa, Trifolium repens or Leucaena leucocephala inoculated with strain CCBAU $65647^{\mathrm{T}}$ or on Mimosa pudica or Indigofera spicata inoculated with strains CCBAU 65643 or CCBAU 65751. This host range differed from those of $R$. multihospitium and $R$. miluonense, which failed to nodulate Phaseolus vulgaris effectively (Han et al., 2008; Gu et al., 2008). The cross-nodulation tests and nodC analysis demonstrated that the test strains were not symbionts of Mimosa pudica or Indigofera spicata, but they might be nodule endophytes of these plants. In addition, strains CCBAU 65643 and CCBAU 65751 might be non-symbiotic bacteria.

Taking into consideration the data from this study and the current criteria of rhizobial species description (Graham et al., 1991; Wayne et al., 1987), we propose the novel group as a novel species of the genus Rhizobium with the name Rhizobium vallis sp. nov. This species can be differentiated genotypically and phenotypically from previously defined species.

\section{Description of Rhizobium vallis sp. nov.}

Rhizobium vallis (val'lis. L. gen. n. vallis of a valley, referring to the fact that the strains were isolated from the Valley of Red River in Yunnan province, China).

Cells are Gram-negative, motile, aerobic, non-spore-forming rods, $1.0-1.5 \mu \mathrm{m} \times 2.0-3.5 \mu \mathrm{m}$. Colonies on YMA are circular, convex, pearl-white, translucent and usually $2-3 \mathrm{~mm}$ in diameter after 3 days of incubation at $28{ }^{\circ} \mathrm{C}$. Strains can grow at $\mathrm{pH} 6.0-9.0$ and cannot grow with up to $1 \%(\mathrm{w} / \mathrm{v})$ $\mathrm{NaCl}$. Optimum growth temperature is $28{ }^{\circ} \mathrm{C}$; cells can grow after exposure to $60{ }^{\circ} \mathrm{C}$ for $10 \mathrm{~min}$ and cannot grow at $10{ }^{\circ} \mathrm{C}$ 
or $37{ }^{\circ} \mathrm{C}$. Tests for catalase, urease, oxidase and litmus milk acid production, acid coagulation and peptonization are positive. Tests for nitrate reductase, cellulose hydrolase, Lphenylalanine deaminase, $\mathrm{H}_{2} \mathrm{~S}$ production and hydrolysis of starch, gelatin, DNA and Tween 80 are negative. Reduces litmus milk, but methyl red and Voges-Proskauer reactions are negative. D-Arabinose, galactitol, D-fructose, D-galactose, glucose, inositol, lactose, sodium malate, maltose, Dmannose, melibiose, raffinose, L-rhamnose, D-ribose, salicin, D-sorbitol, sucrose, trehalose, D-xylose, and DL-proline can be used as sole carbon sources. Strains grow weakly on media with adipate, melezitose, D-amygdalin, calcium gluconate, calcium malonate, dextrin, meso-erythrose, inulin, sodium pyruvate, sodium acetate, sodium citrate, sodium formate, sodium gluconate, sodium succinate, sodium hippurate, sorbose, starch, syringic acid, potassium sodium tartrate or vanillic acid as sole carbon source. DL-Alanine, L-arginine, L-aspartic acid, L-cystine, L-glutamic acid, hypoxanthine, Lisoleucine, L-lysine, L-phenylalanine, L-threonine, L-methionine, D-valine and DL-proline are used as sole nitrogen sources. Resistant to $\left(\mu \mathrm{g} \mathrm{ml}^{-1}\right)$ kanamycin (5) and neomycin (5); and sensitive to ampicillin (50), kanamycin (50), neomycin (50), erythromycin (5), gentamicin sulfate (5) and streptomycin sulfate (5). The pattern of cellular fatty acids of the type strain is given in Supplementary Table S2.

The type strain, CCBAU $65647^{\mathrm{T}}\left(=\mathrm{LMG} 25295^{\mathrm{T}}=\right.$ HAMBI $\left.3073^{\mathrm{T}}\right)$, was isolated from root nodules of Phaseolus vulgaris and its DNA G+C content is $60.9 \mathrm{~mol} \%\left(T_{\mathrm{m}}\right)$.

\section{Acknowledgements}

This work was supported by the foundation of the State Key Basic Research and Development Plan of China (2006CB100206), National Program for Basic S \& T Platform Construction (2005DKA21201-10) and the National Natural Science Foundation of China (30670001 and 30400001). E. T. W. was supported by projects authorized by IPN, Mexico (SIP20090179 and SIP20100067).

\section{References}

Chen, W. X., Yan, G. H. \& Li, J. L. (1988). Numerical taxonomic study of fast-growing soybean rhizobia and proposal that Rhizobium fredii be assigned to Sinorhizobium gen. nov. Int J Syst Bacteriol 38, 392-397.

Chen, W. X., Wang, E. T., Wang, S. Y., Li, Y. B., Chen, X. Q. \& Li, Y. (1995). Characteristics of Rhizobium tianshanense sp. nov., a moderately and slowly growing root nodule bacterium isolated from an arid saline environment in Xinjiang, People's Republic of China. Int J Syst Bacteriol 45, 153-159.

de Bruijn, F. J. (1992). Use of repetitive (repetitive extragenic palindromic and enterobacterial repetitive intergeneric consensus) sequences and the polymerase chain reaction to fingerprint the genomes of Rhizobium meliloti isolates and other soil bacteria. Appl Environ Microbiol 58, 2180-2187.

De Ley, J., Cattoir, H. \& Reynaerts, A. (1970). The quantitative measurement of DNA hybridization from renaturation rates. Eur $J$ Biochem 12, 133-142.

Diouf, A., de Lajudie, P., Neyra, M., Kersters, K., Gillis, M., MartinezRomero, E. \& Gueye, M. (2000). Polyphasic characterization of rhizobia that nodulate Phaseolus vulgaris in West Africa (Senegal and Gambia). Int J Syst Evol Microbiol 50, 159-170.

Frank, B. (1889). Über die Pilzsymbiose der Leguminosen. Ber Dtsch Bot Ges 7, 332-346 (in German).

Gao, J. L., Sun, J. G., Li, Y., Wang, E. T. \& Chen, W. X. (1994). Numerical taxonomy and DNA relatedness of tropical rhizobia isolated from Hainan Province, China. Int J Syst Bacteriol 44, 151-158.

Gaunt, M. W., Turner, S. L., Rigottier-Gois, L., Lloyd-Macgilp, S. A. \& Young, J. P. W. (2001). Phylogenies of atpD and recA support the small subunit rRNA-based classification of rhizobia. Int J Syst Evol Microbiol 51, 2037-2048.

Graham, P. H., Sadowsky, M. J., Keyser, H. H., Barnet, Y. M., Bradley, R. S., Cooper, J. E., De Ley, D. J., Jarvis, B. D. W., Roslycky, E. B. \& other authors (1991). Proposed minimal standards for the description of new genera and species of root-and stem-nodulating bacteria. Int J Syst Bacteriol 41, 582-587.

Gu, C. T., Wang, E. T., Tian, C. F., Han, T. X., Chen, W. F., Sui, X. H. \& Chen, W. X. (2008). Rhizobium miluonense sp. nov., a symbiotic bacterium isolated from Lespedeza root nodules. Int J Syst Evol Microbiol 58, 1364-1368.

Guan, S. H., Chen, W. F., Wang, E. T., Lu, Y. L., Yan, X. R., Zhang, X. X. \& Chen, W. X. (2008). Mesorhizobium caraganae sp. nov., a novel rhizobial species nodulated with Caragana spp. in China. Int J Syst Evol Microbiol 58, 2646-2653.

Han, T. X., Wang, E. T., Wu, L. J., Chen, W. F., Gu, J. G., Gu, C. T., Tian, C. F. \& Chen, W. X. (2008). Rhizobium multihospitium sp. nov., isolated from multiple legume species native of Xinjiang, China. Int $J$ Syst Evol Microbiol 58, 1693-1699.

Hou, B. C., Wang, E. T., Li, Y., Jr, Jia, R. Z., Chen, W. F., Gao, Y., Dong, R. J. \& Chen, W. X. (2009). Rhizobium tibeticum sp. nov., a symbiotic bacterium isolated from Trigonella archiducis-nicolai (Sirj.) Vassilcz. Int J Syst Evol Microbiol 59, 3051-3057.

Huber, I. \& Selenska-Pobell, S. (1994). Characterization of Rhizobium galegae by REP-PCR, PFGE and 16S rRNA sequencing. In Symbiotic Nitrogen Fixation, pp. 153-158. Edited by P. H. Graham, M. J. Sadowsky \& C. P. Vance. Dordrecht: Kluwer.

Hurek, T., Wagner, B. \& Reinhold-Hurek, B. (1997). Identification of $\mathrm{N}_{2}$-fixing plant- and fungus-associated Azoarcus species by PCRbased genomic fingerprints. Appl Environ Microbiol 63, 4331-4339.

Jordan, D. C. (1982). Transfer of Rhizobium japonicum Buchanan 1980 to Bradyrhizobium gen. nov., a genus of slow-growing, root nodule bacteria from leguminous plants. Int J Syst Bacteriol 32, 136139.

Judd, A. K., Schneider, M., Sadowsky, M. J. \& de Bruijn, F. J. (1993). Use of repetitive sequences and the polymerase chain reaction technique to classify genetically related Bradyrhizobium japonicum serocluster 123 strains. Appl Environ Microbiol 59, 1702-1708.

Jukes, T. H. \& Cantor, C. R. (1969). Evolution of protein molecules. In Mammalian Protein Metabolism, vol. 3, pp. 21-132. Edited by H. N. Munro. New York: Academic Press.

Kalita, M., Stepkowski, T., kotocka, B. \& Małek, W. (2006). Phylogeny of nodulation genes and symbiotic properties of Genista tinctoria bradyrhizobia. Arch Microbiol 186, 87-97.

Kimura, M. (1983). The Neutral Theory of Molecular Evolution. Cambridge: Cambridge University Press.

Laguerre, G., Nour, S. M., Macheret, V., Sanjuan, J., Drouin, P. \& Amarger, N. (2001). Classification of rhizobia based on nodC and nifH gene analysis reveals a close phylogenetic relationship among Phaseolus vulgaris symbionts. Microbiology 147, 981-993.

Laranjo, M., Alexandre, A., Rivas, R., Velázquez, E., Young, J. P. \& Oliveira, S. (2008). Chickpea rhizobia symbiosis genes are highly 
conserved across multiple Mesorhizobium species. FEMS Microbiol Ecol 66, 391-400.

Marmur, J. (1961). A procedure for the isolation of deoxyribonucleic acid from microorganisms. J Mol Biol 3, 208-218.

Marmur, J. \& Doty, P. (1962). Determination of the base composition of deoxyribonucleic acid from its thermal denaturation temperature. J Mol Biol 5, 109-118.

Martens, M., Dawyndt, P., Coopman, R., Gillis, M., De Vos, P. \& Willems, A. (2008). Advantages of multilocus sequence analysis for taxonomic studies: a case study using 10 housekeeping genes in the genus Ensifer (including former Sinorhizobium). Int J Syst Evol Microbiol 58, 200-214.

Nick, G. \& Lindstrom, K. (1994). Use of repetitive sequences and the polymerase chain reaction to fingerprint the genomic DNA of Rhizobium galegae strains and to identify the DNA obtained by sonicating the liquid cultures and root nodules. Syst Appl Microbiol 17, 265-273.

Nick, G., Rasanen, L. A., de Lajudie, P., Gillis, M. \& Lindstrom, K. (1999). Genomic screening of rhizobia isolated from root nodules of tropical leguminous trees using DNA-DNA dot-blot hybridization and rep-PCR. Syst Appl Microbiol 22, 287-299.

Quan, Z. X., Bae, H. S., Baek, J. H., Chen, W. F., Im, W. T. \& Lee, S. T. (2005). Rhizobium daejeonense sp. nov. isolated from a cyanide treatment bioreactor. Int J Syst Evol Microbiol 55, 2543-2549.

Ren, W., Chen, W. F., Sui, X. H., Wang, E. T. \& Chen, W. X. (2011). Rhizobium vignae sp. nov., a symbiotic bacterium isolated from multiple legume species. Int J Syst Evol Microbiol 61, 580-586.

Sarita, S., Sharma, P. K., Priefer, U. B. \& Prell, J. (2005). Direct amplification of rhizobial nodC sequences from soil total DNA and comparison to nodC diversity of root nodule isolates. FEMS Microbiol Ecol 54, 1-11.

Schutter, M. E. \& Dick, R. P. (2000). Comparison of fatty acid methyl ester (FAME) methods for characterizing microbial communities. Soil Sci Soc Am J 64, 1659-1668.

Tajima, F. \& Nei, M. (1984). Estimation of evolutionary distance between nucleotide sequences. Mol Biol Evol 1, 269-285.

Tamura, K. \& Nei, M. (1993). Estimation of the number of nucleotide substitutions in the control region of mitochondrial DNA in humans and chimpanzees. Mol Biol Evol 10, 512-526.

Tamura, K., Dudley, J., Nei, M. \& Kumar, S. (2007). MEGA4: molecular evolutionary genetics analysis (MEGA) software version 4.0. Mol Biol Evol 24, 1596-1599.

Tan, Z. Y., Xu, X. D., Wang, E. T., Gao, J. L., Martinez-Romero, E. \& Chen, W. X. (1997). Phylogenetic and genetic relationships of Mesorhizobium tianshanense and related rhizobia. Int J Syst Bacteriol 47, 874-879.

Terefework, Z., Kaijalainen, S. \& Lindström, K. (2001). AFLP fingerprinting as a tool to study the genetic diversity of Rhizobium galegae isolated from Galega orientalis and Galega officinalis. J Biotechnol 91, 169-180.

Tighe, S. W., de Lajudie, P., Dipietro, K., Lindström, K., Nick, G. \& Jarvis, B. D. W. (2000). Analysis of cellular fatty acids and phenotypic relationships of Agrobacterium, Bradyrhizobium, Mesorhizobium,
Rhizobium and Sinorhizobium species using the Sherlock Microbial Identification System. Int J Syst Evol Microbiol 50, 787-801.

Trujillo, M. E., Willems, A., Abril, A., Planchuelo, A. M., Rivas, R., Ludeña, D., Mateos, P. F., Martínez-Molina, E. \& Velázquez, E. (2005). Nodulation of Lupinus albus by strains of Ochrobactrum lupini sp. nov. Appl Environ Microbiol 71, 1318-1327.

Turner, S. L. \& Young, J. P. (2000). The glutamine synthetases of rhizobia: phylogenetics and evolutionary implications. Mol Biol Evol 17, 309-319.

Valverde, A., Igual, J. M., Peix, A., Cervantes, E. \& Velázquez, E. (2006). Rhizobium lusitanum sp. nov. a bacterium that nodulates Phaseolus vulgaris. Int J Syst Evol Microbiol 56, 2631-2637.

van Berkum, P., Badri, Y., Elia, P., Aouani, M. E. \& Eardly, B. D. (2007). Chromosomal and symbiotic relationships of rhizobia nodulating Medicago truncatula and M. laciniata. Appl Environ Microbiol 73, 7597-7604.

Vauterin, L. \& Vauterin, P. (1992). Computer-aided objective comparison of electrophoresis patterns for grouping and identification of microorganisms. Eur Microbiol 1, 37-41.

Versalovic, J., Schneider, M., De Bruijn, F. J. \& Lupski, J. R. (1994). Genomic fingerprinting of bacteria using repetitive sequence-based polymerase chain reaction. Methods Mol Cell Biol 5, 25-40.

Vincent, J. M. (1970). A Manual for the Practical Study of Root-Nodule Bacteria. Oxford: Blackwell Scientific.

Vinuesa, P., Silva, C., Lorite, M. J., Izaguirre-Mayoral, M. L., Bedmar, E. J. \& Martínez-Romero, E. (2005a). Molecular systematics of rhizobia based on maximum likelihood and Bayesian phylogenies inferred from $r r s, a t p D, r e c A$ and nifH sequences, and their use in the classification of Sesbania microsymbionts from Venezuelan wetlands. Syst Appl Microbiol 28, 702-716.

Vinuesa, P., Silva, C., Werner, D. \& Martínez-Romero, E. (2005b). Population genetics and phylogenetic inference in bacterial molecular systematics: the roles of migration and recombination in Bradyrhizobium species cohesion and delineation. Mol Phylogenet Evol 34, 29-54.

Wang, F. Q., Wang, E. T., Zhang, Y. F. \& Chen, W. X. (2006). Characterization of rhizobia isolated from Albizia spp. in comparison with microsymbionts of Acacia spp. and Leucaena leucocephala grown in China. Syst Appl Microbiol 29, 502-517.

Wayne, L. G., Brenner, D. J., Colwell, R. R., Grimont, P. A. D., Kandler, O., Krichevsky, M. I., Moore, L. H., Moore, W. E. C., Murray, R. G. E. \& other authors (1987). Report of the ad hoc committee on reconciliation of approaches to bacterial systematics. Int J Syst Bacteriol 37, 463-464.

Yoon, J. H., Kang, S. J., Yi, H. S., Oh, T. K. \& Ryu, C. M. (2010). Rhizobium soli sp. nov., isolated from soil. Int J Syst Evol Microbiol 60, 1387-1393.

Zhang, R. J., Hou, B. C., Wang, E. T., Li, Y., Jr, Zhang, X. X. \& Chen, W. X. (2011a). Rhizobium tubonense sp. nov., isolated from root nodules of Oxytropis glabra. Int J Syst Evol Microbiol 61, 512-517.

Zhang, G. X., Ren, S. Z., Xu, M. Y., Zeng, G. Q., Luo, H. D., Chen, J. L., Tan, Z. Y. \& Sun, G. P. (2011b). Rhizobium borbori sp. nov., anilinedegrading bacteria isolated from activated sludge. Int J Syst Evol Microbiol 61, 816-822. 